\title{
IMPACT TOUGHNESS OF WMD AFTER MAG WELDING WITH MICRO-JET COOLING
}

\author{
UDARNA ŽILAVOST WMD PO MAG VARJENJU Z MIKRO-JET \\ HLAJENJEM
}

\author{
Tomasz Wegrzyn', Jan Piwnik ${ }^{2}$, Aleksander Borek ${ }^{3}$, Agnieszka Kurc-Lisiecka ${ }^{4}$ \\ ${ }^{1}$ Silesian University of Technology, Faculty of Transport, Krasińkiego 8, 40-019 Katowice, Poland \\ ${ }^{2}$ Bialystok University of Technology, Mechanical Faculty, Wiejska 45c, 16-351 Bialystok, Poland \\ 3Plasma-system, Towarowa 14, 41-103 Siemianowice Śląskie, Poland \\ ${ }^{4}$ University of Dąbrowa Górnicza, Rail Transport Department, Cieplaka 1c, 41-300 Dąbrowa Górnicza, Poland \\ a.kurc@wp.pl \\ Prejem rokopisa - received: 2015-06-30; sprejem za objavo - accepted for publication: 2015-11-05
}

\author{
doi:10.17222/mit.2015.159
}

The MAG welding process with micro-jet cooling of the weld during the cooling stage was investigated. For micro-jet gases the mixtures of argon with carbon dioxide, oxygen, and nitrogen were tested. This paper presents a piece of information about a new proposal for gas mixtures during micro-jet cooling after welding. Presented is the main information about the influence of various micro-jet gas mixtures on the metallographic structure of the weld metal. The mechanical properties of the welds were presented in terms of various gas mixtures selection for micro-jet cooling. The influence of argon gas mixtures with oxygen and nitrogen for micro-jet cooling after welding are reported for the first time in the technical literature.

Keywords: welding, micro-jet cooling, weld, metallographic structure, gas mixtures, GMA welding

Preiskovana je bila začetna faza postopka MAG varjenja z mikro-jet hlajenjem zvara. Za mikro-jet so bile preizkušene mešanice argona z ogljikovim dioksidom, kisikom in dušikom. Clanek predstavlja del informacije o predlogu novih mešanic plinov za mikro-jet hlajenje po varjenju. Dane so informacije o vplivu različnih plinskih mešanic za mikro-jet na metalografske strukture zvarjenega materiala. Mehanske lastnosti zvarov so prikazane v smislu izbranih različnih vrst mešanic plinov za mikro-jet hlajenje. Vpliv mešanice argona s kisikom in dušikom za mikro-jet hlajenje po varjenju je prvič prikazan tudi v tehniški literaturi.

Ključne besede: varjenje, mikro-jet hlajenje, zvar, metalografska struktura, mešanice plinov, GMA varjenje

\section{INTRODUCTION}

MAG is an important industrial welding process, preferred for its versatility, speed and the relative ease of adapting the process to robotic automation. Developments in arc welding processes are strongly related with the need to increase productivity without losing the quality of the weld. ${ }^{1-5}$ The reduction of costs and competitive pricing are each day more strongly related with technological innovations. ${ }^{6-11}$ The properties of steel welded structures depend on many factors such as welding technology, filler materials, state of stress. The main role of these conditions is also connected with the materials, the chemical composition of steel and the weld metal deposit (WMD). ${ }^{12-16}$ The chemical composition of metal weld deposit could be regarded as a very important factor influencing the properties of the weld metal deposit (WMD). In particular, the oxygen, titanium, manganese and aluminium are regarded as the main elements that positively effect the mechanical properties and the metallographic structure of low-alloy welds. This is because of the non-metallic inclusions in weld (Figure 1) that have similar lattice parameter as the ferrite ( $\mathrm{TiO}$, $\mathrm{TiN}, \mathrm{MnO}, \mathrm{Al}_{2} \mathrm{O}_{3}$ ).

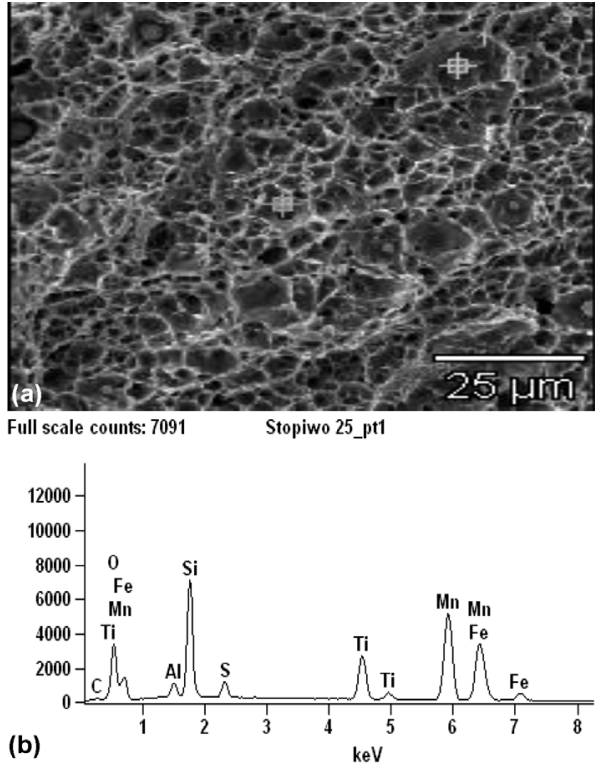

Figure 1: a) SEM micrographs showing the oxide inclusions in low-alloy WMD after welding with basic electrodes and b) EDS analysis of the WMD ${ }^{1}$

Slika 1: a) SEM-posnetek prikazuje oksidne vključke v malo legiranem WDM po varjenju z bazičnimi elektrodami in b) EDS analiza $\mathrm{WMD}^{1}$ 
The welding parameters, metallographic structure and chemical composition of the weld metal deposit are regarded as important factors that influence the impact toughness properties of the deposits. ${ }^{9-12}$ In a typical lowalloy steel weld structure the best mechanical properties correspond with the maximum amount of acicular ferrite (AF) in the weld metal deposit (WMD) and the minimum amount of MAC phases (self-tempered martensite, retained austenite, carbide). This article focuses on mild-steel welding and covers the new possibilities of that method. Since 2011, innovative welding technology based on micro-jet cooling just after welding has been investigated. The weld metal deposit (WMD) was carried out for the standard MAG process and for the innovative welding method with micro-jet cooling. A very high percentage of acicular ferrite (AF) in WMD was obtainable (55-73\%) for low-alloy steel welding only for micro-jet cooling after the MIG process with argon or helium. ${ }^{13-18}$ Argon and helium, as micro-jet gases, could provide a better impact toughness of the WMD $(0.08 \%$ C, $0.8 \%$ $\mathrm{Mn}$ ) than in the case of the classic MAG process (Table 1). Table 1 shows that argon is a more beneficial microjet cooling gas than helium. Also, it is shown that micro-jet cooling improves the amount of acicular ferrite in the weld. Helium is not such a beneficial micro-jet gas as argon and its mixtures in the MAG process (because of the high percentage of MAC phases). In that paper gas mixtures of argon with a small amount of oxygen and nitrogen were mainly tested because of the positive influence of some oxide and nitride inclusions of acicular ferrite forming and thus the very good impact toughness of the welds.

Table 1: Metallographic structure of MAG welds ${ }^{1}$ Tabela 1: Metalografske strukture MAG zvarov ${ }^{1}$

\begin{tabular}{|c|c|c|}
\hline Micro-jet gases & Ferrite AF & MAC phases \\
\hline without micro-jet & $43 \%$ & $4 \%$ \\
\hline $\mathrm{He}$ & $59 \%$ & $6 \%$ \\
\hline $\mathrm{Ar}$ & $63 \%$ & $2 \%$ \\
\hline
\end{tabular}

\section{EXPERIMENTAL PART}

The weld metal deposit was prepared by welding with micro-jet cooling with gas mixtures both for the standard MAG process and the MAG welding with micro-jet cooling. The MAG welding process was based on a shielded gas mixture of $79 \% \mathrm{Ar}$ and $21 \% \mathrm{CO}_{2}$. To obtain various amounts of acicular ferrite in the WMD the installed micro-jet injector was close to the MAG welding head. The main parameters of the micro-jet cooling were slightly varied:

- cooling steam diameter (40 $\mu \mathrm{m}$ and $50 \mu \mathrm{m})$,

- gas pressure (0.4 MPa and 0.5 MPa),

- gas mixtures of argon $\left(82 \% \mathrm{Ar} / 18 \% \mathrm{CO}_{2}\right.$ and $98 \%$ $\mathrm{Ar} / 2 \% \mathrm{O}_{2}$ and $98 \% \mathrm{Ar}+2 \% \mathrm{~N}_{2}$ ) were chosen as the micro-jet gases.

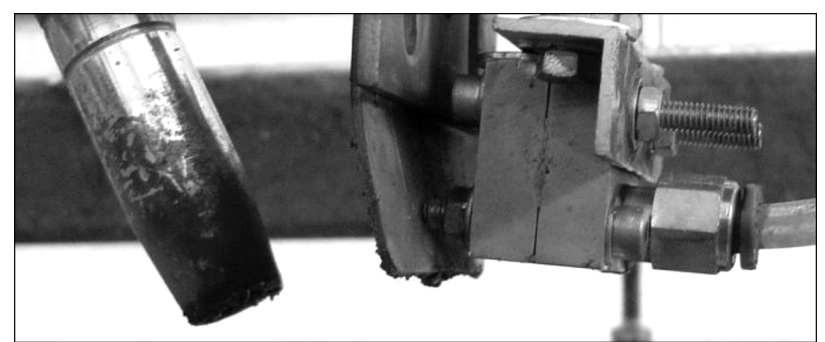

Figure 2: Montage of welding head and micro-jet injector (on the right)

Slika 2: Namestitev varilne glave in mikro-jet injector (na desni)

A montage of the welding head and the micro-jet injector is illustrated in Figure 2. The main data about the parameters of the welding are shown in Table 2. The weld metal deposit was prepared by welding with micro-jet cooling using a larger number of parameters (Table 3).

Table 2: Parameters of the welding process

Tabela 2: Parametri procesa varjenja

\begin{tabular}{|c|c|c|}
\hline No. & Parameter & Value \\
\hline 1. & Diameter of wire & $1.2 \mathrm{~mm}$ \\
\hline 2. & Standard current & $220 \mathrm{~A}$ \\
\hline 3. & Voltage & $24 \mathrm{~V}$ \\
\hline 4. & Shielding welding gases & $82 \% \mathrm{Ar} / 18 \% \mathrm{CO}_{2}$ \\
\hline 5. & $\begin{array}{c}\text { Kind of tested micro-jet } \\
\text { cooling gases }\end{array}$ & $\begin{array}{c}\mathrm{Ar}, 82 \% \mathrm{Ar} / 18 \% \mathrm{CO}_{2} \\
98 \% \mathrm{Ar} / 2 \% \mathrm{O}_{2} \\
98 \% \mathrm{Ar} / 2 \% \mathrm{~N}_{2}\end{array}$ \\
\hline 6. & Gas pressure & $0.4 \mathrm{MPa} ; 0.5 \mathrm{MPa}$ \\
\hline 7. & Number of micro-jets & 1 \\
\hline 8. & Cooling stream diameter & $40 \mu \mathrm{m} ; 50 \mu \mathrm{m}$ \\
\hline
\end{tabular}

Table 3: Chemical composition of WMD

Tabela 3: Kemijska sestava WDM

\begin{tabular}{|c|c|c|}
\hline Comment & Element & Amount \\
\hline in all tested cases & $\mathrm{C}$ & $0.08 \%$ \\
\hline in all tested cases & $\mathrm{Mn}$ & $0.79 \%$ \\
\hline in all tested cases & $\mathrm{Si}$ & $0.39 \%$ \\
\hline in all tested cases & $\mathrm{P}$ & $0.017 \%$ \\
\hline in all tested cases & $\mathrm{S}$ & $0.018 \%$ \\
\hline
\end{tabular}

\section{RESULTS AND DISCUSSION}

We tested and compared various welds of the standard MAG process connected with those of the innovative micro-jet cooling. A typical weld metal deposit had a similar chemical composition in all the tested cases. The micro-jet gas could only have an influence on more or less intensive cooling conditions, but it does not have any influence on the chemical WMD composition (Table 3), except for the oxygen and nitrogen amounts in the WMD (Table 4).

It is easy to deduce that the amount of oxygen and nitrogen was slightly increased in terms of the chemical composition of the micro-jet gas mixtures. After the chemical analyses the metallographic structure of the WMD 
(with and without micro-jet cooling) was carried out. An example of this structure was shown in Table 5.

Table 4: Content of oxygen and nitrogen in WMD

Tabela 4: Vsebnost kisika in dušika v WMD

\begin{tabular}{|c|c|c|}
\hline Micro-jet gases & Element & Amount (\%) \\
\hline $\mathrm{Ar}$ & $\mathrm{O}$ & 0.0350 \\
\hline $82 \% \mathrm{Ar} / 18 \% \mathrm{CO}_{2}$ & $\mathrm{O}$ & 0.0380 \\
\hline $98 \% \mathrm{Ar} / 2 \% \mathrm{O}_{2}$ & $\mathrm{O}$ & 0.0380 \\
\hline $98 \% \mathrm{Ar} / 2 \% \mathrm{~N}_{2}$ & $\mathrm{O}$ & 0.0350 \\
\hline $\mathrm{Ar}$ & $\mathrm{N}$ & 0.0055 \\
\hline $82 \% \mathrm{Ar} / 18 \% \mathrm{CO}_{2}$ & $\mathrm{~N}$ & 0.0055 \\
\hline $98 \% \mathrm{Ar} / 2 \% \mathrm{O}_{2}$ & $\mathrm{~N}$ & 0.0055 \\
\hline $98 \% \mathrm{Ar} / 2 \% \mathrm{~N}_{2}$ & $\mathrm{~N}$ & 0.0060 \\
\hline
\end{tabular}

Table 5: Metallographic structure of (MAG method $82 \%$ Ar/18\% $\mathrm{CO}_{2}$ ) welds

Tabela 5: Metalografska struktura zvarov (metoda MAG z $82 \%$ $\left.\mathrm{Ar} / 18 \% \mathrm{CO}_{2}\right)$

\begin{tabular}{|c|c|c|c|c|}
\hline Micro-jet gas & $\begin{array}{c}\text { Gas } \\
\text { pressure, } \\
\mathrm{MPa}\end{array}$ & $\begin{array}{c}\text { Cooling } \\
\text { steam } \\
\text { diameter, } \\
\mu \mathrm{m}\end{array}$ & $\begin{array}{c}\text { Ferrite } \\
\mathrm{AF}\end{array}$ & $\begin{array}{c}\text { MAC } \\
\text { phases }\end{array}$ \\
\hline without micro-jet & - & - & $55 \%$ & $3 \%$ \\
\hline $\mathrm{Ar}$ & 0.4 & 40 & $60 \%$ & $2 \%$ \\
\hline $\mathrm{Ar}$ & 0.4 & 50 & $63 \%$ & $2 \%$ \\
\hline $\mathrm{Ar}$ & 0.5 & 40 & $63 \%$ & $2 \%$ \\
\hline $\mathrm{Ar}$ & 0.5 & 50 & $61 \%$ & $2 \%$ \\
\hline $98 \% \mathrm{Ar} / 2 \% \mathrm{O}_{2}$ & 0.4 & 40 & $64 \%$ & $2 \%$ \\
\hline $98 \% \mathrm{Ar} / 2 \% \mathrm{O}_{2}$ & 0.4 & 50 & $66 \%$ & $2 \%$ \\
\hline $98 \% \mathrm{Ar} / 2 \% \mathrm{O}_{2}$ & 0.5 & 40 & $67 \%$ & $2 \%$ \\
\hline $98 \% \mathrm{Ar} / 2 \% \mathrm{O}_{2}$ & 0.5 & 50 & $65 \%$ & $2 \%$ \\
\hline $82 \% \mathrm{Ar} / 18 \% \mathrm{CO}_{2}$ & 0.4 & 40 & $58 \%$ & $2 \%$ \\
\hline $82 \% \mathrm{Ar} / 18 \% \mathrm{CO}_{2}$ & 0.4 & 50 & $60 \%$ & $2 \%$ \\
\hline $82 \% \mathrm{Ar} / 18 \% \mathrm{CO}_{2}$ & 0.5 & 40 & $61 \%$ & $2 \%$ \\
\hline $82 \% \mathrm{Ar} / 18 \% \mathrm{CO}_{2}$ & 0.5 & 50 & $59 \%$ & $3 \%$ \\
\hline $98 \% \mathrm{Ar} / 2 \% \mathrm{~N}_{2}$ & 0.4 & 40 & $58 \%$ & $2 \%$ \\
\hline $98 \% \mathrm{Ar} / 2 \% \mathrm{~N}_{2}$ & 0.4 & 50 & $59 \%$ & $2 \%$ \\
\hline $98 \% \mathrm{Ar} / 2 \% \mathrm{~N}_{2}$ & 0.5 & 40 & $59 \%$ & $2 \%$ \\
\hline $98 \% \mathrm{Ar} / 2 \% \mathrm{~N}_{2}$ & 0.5 & 50 & $57 \%$ & $3 \%$ \\
\hline
\end{tabular}

Table 5 shows that in all cases a gas mixture of argon with oxygen is the most beneficial choice. We also observed MAC (self-tempered martensite, retained austenite, carbide) phases on various levels. In the standard MAG welding process (without micro-jet cooling) there are usually gettable larger amounts of grain-boundary ferrite (GBF) and site-plate ferrite (SPF) fraction, meanwhile in micro-jet cooling WMD both of the GBF and SPF structures were not so dominant. Ferrite with a percentage above $60 \%$ was gettable only in one case after MAG welding with micro-jet gas mixtures: argon/oxygen or argon/carbon dioxide (Figure 3).

The larger amount of MAC phases was especially gettable for the more intensive micro-jet cooling with a gas mixture of argon-oxygen (Tables 5 and 6). The heat-transfer coefficient of the various micro-jet gas mixtures influences the cooling conditions of the welds (and consequently the rise in the content of the MAC

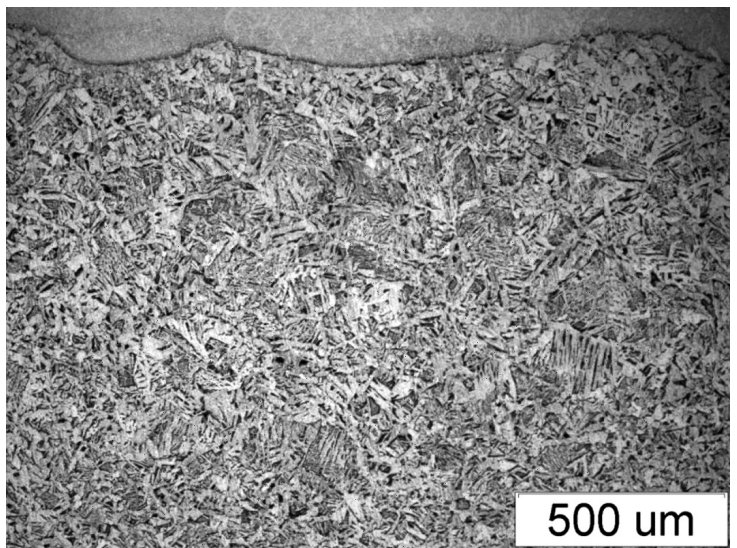

Figure 3: Microstructure weld metal with large amount of acicular ferrite in weld $(67 \%)$ after $\mathrm{Ar} / \mathrm{CO}_{2}$ micro-jet cooling

Slika 3: Mikrostruktura zvara z velikim deležem igličastega ferita v zvaru (67\%), po mikro-jet hlajenju z $\mathrm{Ar} / \mathrm{CO}_{2}$

phases). This is due to the conductivity coefficients $\left(\lambda \cdot 10^{5}\right)$, as shown in Table 6 .

Table 6: Heat-transfer coefficient of various gases used in micro-jet cooling

Tabela 6: Koeficient prenosa toplote različnih plinov, uporabljenih pri mikro-jet hlajenju

\begin{tabular}{|c|c|}
\hline Gas & $\begin{array}{c}\text { Conductivity coefficients, } \\
\mathrm{mW} / \mathrm{mK}\end{array}$ \\
\hline $\mathrm{Ar}$ & 17.9 \\
\hline $\mathrm{CO}_{2}$ & 16.8 \\
\hline $\mathrm{O}_{2}$ & 26.3 \\
\hline $\mathrm{N}_{2}$ & 26 \\
\hline $\mathrm{He}$ & 156.7 \\
\hline
\end{tabular}

Table 7: Metallographic structure of MAG $\left(82 \% \mathrm{Ar} / 18 \% \mathrm{CO}_{2}\right)$ welds Tabela 7: Metalografska struktura MAG zvarov (82\% Ar/18 \% $\mathrm{CO}_{2}$ )

\begin{tabular}{|c|c|c|c|}
\hline Welding method & $\begin{array}{l}\text { Micro-jet } \\
\text { gas }\end{array}$ & \begin{tabular}{|c|} 
Test \\
temperature, \\
${ }^{\circ} \mathrm{C}$
\end{tabular} & $\begin{array}{c}\text { Impact } \\
\text { toughness } \\
\mathrm{KCV}, \mathrm{J}\end{array}$ \\
\hline MAG & without & -40 & below 40 \\
\hline $\begin{array}{l}\text { MAG with micro-jet } \\
\text { cooling }\end{array}$ & Ar & -40 & 55 \\
\hline $\begin{array}{l}\text { MAG with micro-jet } \\
\text { cooling }\end{array}$ & $\begin{array}{l}82 \% \mathrm{Ar} / \\
18 \% \mathrm{CO}_{2} \\
\end{array}$ & -40 & 53 \\
\hline $\begin{array}{l}\text { MAG with micro-jet } \\
\text { cooling }\end{array}$ & $\begin{array}{c}98 \% \mathrm{Ar} / \\
2 \% \mathrm{O}_{2}\end{array}$ & -40 & 57 \\
\hline $\begin{array}{l}\text { MAG with micro-jet } \\
\text { cooling }\end{array}$ & $\begin{array}{l}98 \% \mathrm{Ar} / \\
2 \% \mathrm{~N}_{2}\end{array}$ & -40 & below 40 \\
\hline MAG & without & +20 & 177 \\
\hline $\begin{array}{l}\text { MAG with micro-jet } \\
\text { cooling }\end{array}$ & $\mathrm{Ar}$ & +20 & 191 \\
\hline $\begin{array}{l}\text { MAG with micro-jet } \\
\text { cooling }\end{array}$ & $\begin{array}{l}82 \% \mathrm{Ar} / \\
18 \% \mathrm{CO}_{2} \\
\end{array}$ & +20 & 189 \\
\hline $\begin{array}{l}\text { MAG with micro-jet } \\
\text { cooling }\end{array}$ & $\begin{array}{c}98 \% \mathrm{Ar} / \\
2 \% \mathrm{O}_{2}\end{array}$ & +20 & 194 \\
\hline $\begin{array}{l}\text { MAG with micro-jet } \\
\text { cooling }\end{array}$ & $\begin{array}{l}98 \% \mathrm{Ar} / \\
2 \% \mathrm{~N}_{2}\end{array}$ & +20 & 183 \\
\hline
\end{tabular}

Analysing Table 6, it is possible to deduce that helium could give the strongest cooling conditions, but helium was not tested in this investigation. The cooling 
conditions after welding using other micro-jet gases are on a similar level. After the microscope tests, the Charpy $\mathrm{V}$ impact toughness of the deposited metal was assessed with 5 specimens. The Charpy tests were carried out at temperatures of $-40{ }^{\circ} \mathrm{C}$ and $+20{ }^{\circ} \mathrm{C}$ only. The impact toughness results are given in Table 7 .

It is easy to deduce that the impact toughness, especially at the negative temperature of the weld metal deposit, is apparently affected by the kind of micro-jet cooling gas mixtures. Micro-jet technology always strongly improves the impact toughness of the WMD. Argon with oxygen and argon with carbon dioxide must be treated as good choices. Argon as the main element of the gas mixture with a small amount of oxygen gives better results than gas mixtures of argon with carbon dioxide and argon with nitrogen. Nevertheless, micro-jet cooling with gas mixture of argon with $2 \%$ of nitrogen gives better results than the simple MAG welding without micro-jet cooling. This can be explained by the presence of nitride inclusions in the weld (for instance $\mathrm{TiN}$ ) that facilitate the nucleation of ferrite AF.

\section{CONCLUSIONS}

In low-alloy steel welding there are two general types of tests performed: impact toughness and structure. Acicular ferrite and MAC phases (self-tempered martensite, upper and lower bainite, retained austenite, carbides) were analysed and counted for each weld metal deposit. These two tests (microstructure and impact toughness) proved that micro-jet technology gives a beneficial modification to the mechanical properties of the welds. The innovative micro-jet technology was firstly recognized with great success for MIG welding only with argon as a micro-jet gas. In this paper micro-jet cooling technology was for the first time described and tested for MAG welding process with various micro-jet gas mixtures of argon.

Final conclusions:

- micro-jet cooling could be treated as an important element of MAG welding process,

- micro-jet cooling after welding can improve the amount of ferrite AF, the most beneficial phase in low-alloy steel WMD,

- gas mixture of argon with carbon dioxide and gas mixture of argon with oxygen could be treated as better micro-jet cooling media than gas mixture of argon with nitrogen,

- micro-jet cooling after welding can seriously improve the impact toughness of low-alloy steel WMD,

- micro-jet cooling after welding practically does not have an influence on the MAC amount in low-alloy steel WMD.

\section{REFERENCES}

${ }^{1}$ T. Węgrzyn, Gas mixtures for welding with micro-jet cooling, Arch. Metall. Mater., 47 (2011), 57-61, doi: 10.1515/amm-2015-0017

${ }^{2}$ B. Slazak, J. Słania, T. Węgrzyn, A.P. Silva, Process stability evaluation of manual metal arc welding using digital signals, Mater. Sci. Forum, 730-732 (2013), 847-852, doi:10.4028/www.scientific.net/ MSF.730-732.847

${ }^{3}$ P. Folega, FEM analysis of the options of using composite materials in flexsplines, Arch. Mater. Sci. Eng., 51 (2011) 1, 55-60

${ }^{4}$ T. Węgrzyn, J. Mirosławski, A. Silva, D. Pinto, M. Miros, Oxide inclusions in steel welds of car body, Mater. Sci. Forum 6 (2010), 585-591, doi:10.4028/www.scientific.net/MSF.636-637.585

${ }^{5}$ T. Kasuya, Y. Hashiba, S. Ohkita, M. Fuji, Hydrogen distribution in multipass submerged arc weld metals, Sci. Tech. Weld. Join., 6 (2011) 4, 261-266, doi:http://dx.doi.org/10.1179/1362171011015 38767

${ }^{6} \mathrm{~J}$. Słania, Influence of phase transformations in the temperature ranges of $1250-1000{ }^{\circ} \mathrm{C}$ and $650-350{ }^{\circ} \mathrm{C}$ on the ferrite content in austenitic welds made with T 2312 LRM3 tubular electrode, Arch. Metall. Mater., 50 (2005), 757-767

${ }^{7}$ W. Tarasiuk, B. Szczucka-Lasota, J. Piwnik, W. Majewski, Hydrogen distribution in multipass submerged arc weld metals, Adv. Mat. Res., 1036 (2014), 452-457, doi: 10.4028/www.scientific.net/AMR. 1036.452

${ }^{8}$ T. Wegrzyn, Mathematical equations of the influence of molybdenum and nitrogen in welds, Conference of International Society of Offshore and Polar Engineers ISOPE'2002, Kita Kyushu, Japan, 2002, Copyright by International Society of Offshore and Polar Engineers, vol. IV, ISBN 1-880653-58-3, Cupertino - California - USA 2002

${ }^{9}$ R. Burdzik, Z. Stanik, J. Warczek, Method of assessing the impact of material properties on the propagation of vibrations excited with a single force impulse, Arch. Metall. Mater., 57 (2012) 2, 409-416

${ }^{10} \mathrm{R}$. Burdzik, Monitoring system of vibration propagation in vehicles and method of analysing vibration modes, Comm. Comp. Inorm. Scie., 329 (2012), 406-413

${ }^{11}$ R. Burdzik, P. Folęga, B. Łazarz, Z. Stanik, J. Warczek, Analysis of the impact of surface layer parameters on wear intensity of friction pairs, Arch. Metall. Mater., 57 (2012) 4, 987-993

${ }^{12}$ K. Lukaszkowicz, A. Kriz, J. Sondor, Structure and adhesion of thin coatings deposited by PVD technology on the X6CrNiMoTi17-12-2 and X40CrMoV5-1 steel substrates, Arch. Mater. Sci. Eng., 51 (2011), 40-47

${ }^{13}$ A. Lisiecki, Diode laser welding of high yield steel, Proc. of SPIE 8703 Vol.8703, Laser Technology 2012: Applications of Lasers, 87030S (January 22, 2013), doi:10.1117/12.2013429

${ }^{14}$ A. Lisiecki, Welding of titanium alloy by Disk laser, Proc. of SPIE Vol. 8703, Laser Technology 2012: Applications of Lasers, 87030T (January 22, 2013), doi: 10.1117/12.2013431

${ }^{15}$ A. Lisiecki, Welding of thermomechanically rolled fine-grain steel by different types of lasers, Arch. Metall. Mater., 59 (2014), 1625-1631, doi: 10.2478/amm-2014-0276

${ }^{16}$ A. Kurc-Lisiecka, W. Ozgowicz, W. Ratuszek, J. Kowalska, Analysis of deformation texture in AISI 304 steel sheets, Sol. St. Phenom., 203-204 (2013), 105-110, doi: 10.4028/www.scientific.net/SSP. 203-204.105

${ }^{17}$ G. Golański, J. Słania, Effect of different heat treatments on microstructure and mechanical properties of the martensitic GX12CrMoVNbN91 cast steel, Arch. Metall. Mater., 58 (2012) 1, 25-30, doi: 10.2478/v10172-012-0145-x

${ }^{18}$ T. Węgrzyn, J. Piwnik, D. Hadryś, R. Wieszała, Car body welding with micro-jet cooling, J.Arch. Mater. Sci. Eng., 49 (2011), 90-94 